Также $\mathrm{SiC}$ обладает отличительными оптическими и фотоэлектрическими свойствами, которые позволяют производить светоизлучающие диоды с излучением любого цвета, от фиолетового до красного.

Как уже говорилось ранее неповторимое сочетание электрических и физикохимических свойств карбида кремния обеспечивает широкие перспективы применения в разных отраслях промышленности.

Приборы на основе карбида кремния широко используются в узлах телекоммуникационного оборудования, авиационной и космической техники, нефтехимии и геофизики. Высокочастотные $\mathrm{SiC}$-приборы применяются в базовых станциях сотовых систем связи, РЛС, бортовых спутниковых системах, военных системах связи, телевизионных спутниковых системах. Кроме того, SiC применяется при изготовлении зеркал лазерных излучателей, излучающих на длине волны 10,6 мкм, зеркал синхротронного излучения, радиационных светоизлучающих диодов и солнечных элементов [1].

Таким образом, технология $\mathrm{SiC}$ на сегодняшний день является очень востребованной и перспективной.

$$
* * *
$$

1. Сорокин В. С., Антипов Б. Л., Лазарева Н. П. Материалы и элементы электронной техники. Проводники, полупроводники, диэлектрики: Учебник. - Т. 1. -2-е изд., испр. - СПб.: Издательство «Лань», 2015. — 448 с.: ил. - (Учебники для вузов. Специальная литература).

2. Ренкель А.Ф. Инноград Sk. История прогресса. / Ренкель А.Ф. // Патент - Евразия №2 (3), 2012.

\title{
Володькин В.П. \\ Влияние добычи нефти на перспективы развития о. Сахалин
}

Санкт-Петербургский горный университет (Россия,Санкт-Петербург)

doi:10.18411/spc-12-04-2018-16

idsp: 000001:spc-12-04-2018-16

Остров Сахалин протянулся с севера на юг почти на 950 км; площадь - 87 тыс. км2 (как Тверская или Ленинградская область), население - около 600 тыс. человек. Остров отделен от материка Татарским проливом, замерзающим зимой. Наименьшая ширина пролива - 7 км. Сахалин состоит как бы из двух частей. Наиболее развитая и населенная южная часть, где расположен административный центр - г. ЮжноСахалинск, связана с материком железнодорожной паромной переправой Холмск Ванино. Менее населенная северная часть с центром в г. Оха долгое время была практически отрезана от южной; лишь недавно их соединило автомобильное шоссе. Такая ситуация исторически объяснима. После проигранной в 1905 году Русскояпонской войны южная часть острова отошла к Японии и вернулась в Россию только в 1946 году, после поражения Японии во Второй мировой войне. Юг Сахалина значительно лучше обустроен и обжит. Этому способствовал и более мягкий климат с незамерзающим морем у порта Корсаков в заливе Анива. От южной оконечности Сахалина до Японского острова Хоккайдо - около 40 км.

Необходимо отметить, что добыча нефти на Сахалине ведется давно. К концу 1928 года трест "Сахалиннефть" добывал в районе Охи 6 тыс. т нефти, к концу первой пятилетки - 240 тыс. т. Столько нефти сам северный Сахалин потребить не мог, и в труднейшем для страны военном, 1942 году был сооружен нефтепровод Оха - Софийск и нефть пошла на материк /1/.

В 1970-х годах уже шла разведка шельфа Сахалина, и вскоре на перспективных структурах пробурили первые скважины, давшие промышленный приток нефти. (Перспективная структура становится месторождением в тот момент, когда на ней из 
пробуренной скважины получен промышленный приток нефти или газа, позволяющий оценить запасы.) Таким образом, были открыты первые крупные нефтегазовые месторождения шельфа России рядом с давно разрабатываемыми наземными. И это неудивительно: на Сахалине геология шельфа и суши едина. Оказалось, что площадь нефтеносного шельфа примерно равна площади всего острова. Большинство месторождений находится в зоне сравнительно малых глубин - до 200 м. Первыми открыли месторождения, находящиеся ближе к берегу: Одопту - в 1977 году, Чайво - в 1979-м, Лунское - в 1984-м, Пильтун-Астохское - в 1986-м, Аркутун-Даги - в 1989-м, а затем и другие. Но еще не опробованных перспективных структур значительно больше; они протянулись с юга, от мыса Терпения, вдоль всего восточного берега острова и уходят за его северную оконечность в море, далеко на север. Следует напомнить, что запасы Охотского моря составляют 15\% запасов шельфа России в целом! Почти все они относятся к шельфу Сахалина $/ 2 /$.

Bce открытые месторождения и перспективные структуры разбиты по географическому принципу на шесть частей. Соответствующие проекты разработки получили названия от Сахалин-1 до Сахалин-6.

Ожидается, что к 2020 году нефтедобыча на Сахалине возрастет с нынешних 2,8 до 30 млн т в год (в двух старых районах нефтедобычи - Охинском и Ногликском, которые продолжают развиваться, сегодня получают по 750 тыс. т нефти в год). Для сравнения: в России в 2004 году добыто 450 млн т нефти, экспортировано около 200 млн т. Добавка к экспорту только от двух первых, уже реализуемых проектов составит 8\%. Причем эта нефть находится на востоке России, откуда до сих пор ее не экспортировали.

Первыми к освоению были намечены прибрежные, сравнительно мелководные месторождения Одопту, Чайво и Аркутун-Даги. Этот проект имеет название Сахалин-1. Затем планировалась разработка проекта Сахалин-2, включающего Пильтун-Астохское нефтяное и Лунское газовое месторождения. Но сложилось так, что работы по проекту Сахалин-2 начались раньше. Именно там в 1998 году была установлена первая в России буровая платформа для добычи нефти на шельфе, а в 1999 году началась промышленная добыча нефти. Июль 1999 года - знаменательная дата для нефтяников России: на шельфе Сахалина, с буровой платформы на Пильтун-Астохском месторождении, добыта первая нефть, загружена в танкер и отправлена потребителю.

Освоение крупного нефтяного месторождения занимает несколько лет; на пик добычи оно выходит лет через десять. Месторождение начнет давать отдачу в полном объеме только тогда, когда добытая нефть дойдет до потребителя. Ведь добыча и транспортировка - это две неразрывные части работы системы. Поэтому в стоимость освоения месторождения входят все расходы, начиная с разведки, организации добычи, капитального строительства и кончая транспортировкой до места продажи, а это трубопроводы, оборудование портов и даже танкеры для перевозки нефти. Кроме того, в нее включаются расходы на обслуживание и налоги. Только после продажи нефти будут получены деньги, окупающие расходы.

Специалисты подсчитали, что с каждого вложенного доллара на разных этапах его использования государство может взять в сумме до 70\% налогов. И это еще не все есть прямые инвестиции в местный бюджет, оговоренные с самого начала. Сотня миллионов долларов - таково ежегодное вложение консорциума Сахалин-2 в бюджет Сахалина, идущее на развитие инфраструктуры острова: строительство и реконструкцию железнодорожной и шоссейной сети, реконструкцию и строительство портов и аэропортов, строительство комфортабельного жилья, увеличение числа гостиниц. Началась газификация региона, в 2003 году подвели газ к Южно-Сахалинску. Все это способствует повышению уровня жизни местного населения.

Помимо этого проекты освоения шельфа местным жителям дают новые рабочие места. Например, до начала их реализации наблюдался отток населения с о.Сахалина. 
Благодаря этим проектам созданы тысячи новых рабочих мест. Ко времени выхода на максимум строительных работ по проекту Сахалин-2 в них было занято 12 тыс. человек (только на строительстве завода СПГ - 6,5 тыс.). Для осуществления работ по проекту Сахалин-1 необходимо 13 тыс. человек.

Сахалинская область - лидер среди субъектов России по темпам экономического развития и привлекаемым прямым иностранным инвестициям. Их сумма за первый квартал 2017 года составила 2 миллиарда 170 миллионов долларов, что составляет почти $80 \%$ от всех инвестиций, привлекаемых в федеральный округ. Во многом это заслуга реализации шельфовых проектов "Сахалин-1" и "Сахалин-2". Благодаря им остров стал глобальным энергетическим центром на Дальнем Востоке.

В 2016 году было добыто более 18 миллионов тонн нефти. По этому показателю Сахалинская область входит в пятерку лидеров среди нефтедобывающих регионов России. Если сравнивать результаты с 2000 годом, то объемы извлеченной нефти увеличились более чем в 5 раз, а газа - почти в 17 раз

Сахалинская область по праву считается одним из ведущих нефтегазоносных районов страны, на ее территории находятся самые современные буровые платформы, построен первый завод по производству сжиженного природного газа, создана уникальная транспортная инфраструктура для экспорта углеводородов.

$$
* * *
$$

1. https://www.nkj.ru/archive/articles/9308/

2. Нефть и газ Сахалина. Материалы международной научно-технической конференции. 25 сентября 2017 года. г.Южно-Сахалинск

3. https://sakhalin.info/news/139552/. 